ISSN: 0213-2079 - ISSN electrónico: 2386-3889

DOI: https://doi.org/10.14201/shhmo2021432339368

\title{
EL CASO DAMIENS Y LA DESACRALIZACIÓN DE LA MONARQUÍA FRANCESA
}

\section{The Damiens Affair and the demystification of the French monarchy}

\author{
Víctor CASES MARTÍNEZ \\ Universidad de Murcia \\ vcases@um.es
}

Fecha de recepción: 8/6/2020

Fecha de aceptación: 18/9/2021

RESUMEN: En 1757 Robert-François Damiens hirió de un navajazo a Luis XV. Las autoridades y la prensa presentaron el atentado como un suceso extraordinario perpetrado por un fanático, que nada tenía que ver con las tensiones que sacudían el país. Sin embargo, la lectura oficial del acontecimiento no silenció los numerosos malos discursos que aplaudían la osadía del frustrado regicida.

El fallido magnicidio puede ser inscrito en una historia de larga duración que muestra cómo algunas de las opciones estratégicas de las autoridades del Antiguo Régimen fueron minando paulatinamente su poderío, como el traslado de Luis XIV a Versalles o la política antijansenista de la Corona.

La desacralización de la monarquía posibilitó la aparición de una nueva elite intelectual, los philosophes, quienes se postularon como los abanderados de la emergente opinión pública, que a su juicio convenía distinguir de la «estúpida y miserable» opinión popular, a la que pertenecía Damiens.

Palabras clave: Robert-François Damiens; desacralización; siglo XVIII; philosophes; opinión pública. 
ABSTRACT: In 1757, Robert-François Damiens injured Louis XV by stabbing him with a penknife. The authorities and the press described the attack as an extraordinary event carried out by a fanatic who had nothing to do with the tensions that were shaking the country. However, the official version of the event did not silence the bad discourses that applauded the audacity of the unsuccessful regicide.

This failed assassination attempt can be framed in a long history which shows how some of the strategical choices made by the authorities of the Ancien Régime undermined gradually their power, such as the transfer of Louis XIV to Versailles or the anti-Jansenist policy of the Crown.

The demystification of the monarchy enabled the rise of a new intellectual elite, the philosophes, who claimed to be the leading lights of the emerging public opinion, which in their view should be distinguished from the «stupid and miserable» popular opinion to which Damiens belonged.

Keywords: Robert-François Damiens; demystification; eighteenth century; philosophes; public opinion.

\section{EL ATENTADO CONTRA LUIS XV}

El lunes tres de enero de 1757 Robert-François Damiens se despidió de su esposa, Elisabeth, y de su hermano Jean-Jacques, a quienes les dijo que abandonaba de nuevo París (de donde había partido en julio del año anterior) para regresar a Flandes. Pero no tomó el camino de la posada donde se refugiaba (la policía francesa lo buscaba tras haber robado 240 luises a su antiguo patrón) y guardaba todo su equipaje, sino que puso rumbo a Versalles. El miércoles salió de la habitación que había alquilado en la Rue de Satory y mientras paseaba supo que aquella tarde el rey se encontraba allí, visitando a su hija favorita, Madame Victoire, que andaba resfriada. Vestido con sombrero y casaca de montar, Damiens no tuvo que vencer ningún obstáculo para entrar en el patio del castillo, e incluso conversó con los guardias antes de sumarse al grupo de sirvientes y soldados que aguardaban a Luis XV. Este descendió la escalinata, acompañado entre otros por el delfín, y al pie de la misma, cuando se disponía a recorrer los escasos metros que lo separaban del carruaje preparado para conducirlo de vuelta a su residencia invernal, sintió cómo alguien lo agarraba del hombro y le propinaba un navajazo en el costado derecho del tórax. Tras unos instantes de confusión, el agresor fue detenido. Además del cortaplumas con el que había herido al monarca, hallaron en sus bolsillos unas pequeñas tijeras, un libro religioso, Prières et instructions chrétiennes, de Pasquier Quesnel, y la suma de 35 luises de oro, que alimentó las sospechas de un regicidio concebido por un grupo de poder que había empleado a Damiens como la mano ejecutora. 
A pesar de que el médico personal de Luis XV, François Quesnay, tranquilizó al rey, pues «no creía que la herida hubiera impedido a cualquier otra persona asistir a un baile» (Van Kley, 1984: 5) ${ }^{1}$, se dispararon de inmediato los rumores sobre el fallecimiento del soberano:

Del miércoles cinco de enero [leemos en el Journal de Barbier (1857-1866: vol. VI, pp. 425-426), uno de los más importantes cronistas de la época]. Este día ha sido testigo del más terrible de los acontecimientos. El Rey ha sido asesinado con una puñalada, entre la cuarta y la quinta costilla del lado derecho, por un criminal, que ha sido atrapado de inmediato y del que no se sabe aún ni el nombre ni la profesión. El jueves por la mañana, día de los Reyes, la consternación era general en París; todo el mundo lloraba en las iglesias; pero a partir de la tarde ha vuelto la felicidad al saber con certeza que la cuchillada no era ni mortal ni peligrosa ${ }^{2}$.

En su correspondencia de Versalles del jueves seis de enero, que vio la luz dos días más tarde - cuando según Barbier (1857-1866: vol. VI, p. 426) el monarca se había levantado y había presidido el Consejo con total normalidad -, la Gazette de France, el periódico oficial del régimen, no escatimaba detalles a la hora de narrar lo ocurrido la fatídica tarde del miércoles:

Ayer a las seis menos cuarto de la tarde, el Rey salió de casa de las Mesdames de Francia y se disponía a subir a su carroza para regresar a Trianon. Un desgraciado encontró entonces la manera de aproximarse a Su Majestad flanqueado por su guardia, sin ser descubierto. Iba armado con un cuchillo de dos hojas, una de ellas era una hoja corriente, la otra tenía la forma de una navaja, de cinco a seis líneas de ancho y alrededor de cuatro piezas de largo. Es con esta última hoja con la que le propinó la puñalada al $\mathrm{Rey}^{3}$.

El texto continúa, da cuenta con suma exactitud de la hondura de la herida y de la reacción de Luis XV al ser acuchillado. Cuando lo que está en juego es la vida del monarca, sin duda los detalles son importantes, como lo son también para

1. «Did not think that the bound have prevented another from attending a ball».

2. «Du mercredi 5 janvier. Ce jour a été témoin du plus affreux des événements. Le Roi a été assassiné d'un coup de couteau, entre la quatrième et la cinquième côte du côté droit, par un scélérat, qui a été pris sur-le-champ, et dont on ne sait encore ni le nom, ni l'état. Le jeudi matin, jour des Rois, la consternation étoit générale dans Paris; tout le monde étoit en pleurs dans les églises; mais, dès le soir, on a eu le bonheur d'apprendre avec certitude que le coup n'étoit ni mortel, ni dangereux».

3. «Hier à Cinq heures trois quarts du soir, le Roi sortit de chez Mesdames de France, pour monter dans son carrosse et se rendre à Trianon. Un malheureux trouva alors le moyen d'approcher Sa Majesté au milieu de sa Garde, sans être aperçu. Il étoit armé d'un couteau à deux lames, dont l'une étoit une lame ordinaire, l'autre avoit la forme d'un canif, et étoit large de 5 à 6 lignes et longue d'environ 4 pouces. C'est avec la dernière lame que le coup a été porté».

Ediciones Universidad de Salamanca / @®@@ Stud. his., H. ${ }^{a}$ mod., 43, n. 2 (2021), pp. 339-368 
comprender las declaraciones del criminal, que en los numerosos interrogatorios a los que fue sometido no cesaba de repetir que nunca quiso matar al soberano, que de haberlo querido a buen seguro lo habría logrado, le habría bastado utilizar la gran hoja de su cuchillo en lugar de la pequeña lámina; según sus propias palabras, lo único que pretendía era «tocar» al rey, «y convencerlo para que escuchara las Remontrances, para que hiciera justicia, para que dejara de prestar atención a los malos consejos de sus Ministros» (Le Breton, 1757: n. 25, p. 331a) ${ }^{4}$.

Las palabras de Damiens revelan, como afirma Pierre Rétat (1979: 223), el sentido más profundo y más dramático del atentado. Obviamente los jueces permanecieron implacables y, como es sabido, quien osó empuñar su cortaplumas contra el monarca fue descuartizado poco después en la Place de Grève, ante la atenta mirada de numerosos espectadores. La lógica del Antiguo Régimen es incontestable en este punto, y el suplicio deviene la consecuencia inevitable: el cuerpo simbólico del rey no acaba de sanar hasta que el cuerpo del criminal es reducido a cenizas, y las cenizas arrojadas al viento. $\mathrm{El}$ atentado por tanto remite al suplicio automáticamente, y este pretende cerrar el círculo o la brecha abierta. Pero la realidad es otra, la respuesta del regicida muestra la cara oculta del gran espectáculo oficial que concluye en la Place de Grève después de tres meses de súplicas, misas, poemas, elogios al Bien Amado y festejos para celebrar su curación. Solo en parte el sobrepoder monárquico ha logrado restaurarse: encerrado primero en la Prévôté del Hotel del Rey en Versalles y más tarde como su predecesor Ravaillac en el Tour de Montgomery, Damiens recuerda, por un lado, el abismo infranqueable que separa a los súbditos de la persona sagrada del rey y denuncia, por otra parte, las funestas decisiones monárquicas de los últimos tiempos (Cases, 2006: 2).

\section{DAMIENS: LA PRENSA Y LOS MALOS DISCURSOS}

Ante todo a partir de la década de 1750, cuando el conflicto jansenista estalla definitivamente al ser negada la extremaunción a todos aquellos que no suscribieran la bula Unigenitus, se desarrolla en Francia una politique de la contestation - por usar los términos de Keith Michael Baker (1987: 41-45) - que no deja títere con cabeza, que arremete aun contra aquellos símbolos que hasta entonces casi habían logrado sustraerse a la crítica. El sistema se desquicia. Se genera un clima de opinión que, según las autoridades, contiene constantemente el germen de la revuelta. Es preciso por tanto redoblar las precauciones y la vigilancia, multiplicar los efectivos dedicados a la escucha clandestina de los gestos y rumores de los cafés, las plazas

4. «Et de le rendre plus disposé à écouter les Remontrances, à faire justice, à ne plus écouter les mauvais conseils de ses Ministres». El fragmento pertenece al interrogatorio del 17 de marzo.

Ediciones Universidad de Salamanca / అ@@ Stud. his., H. ${ }^{a}$ mod., 43, n. 2 (2021), pp. 339-368 
y los mercados públicos 5 . Como no podía ser de otra manera, tras el intento de regicidio el estrechamiento del cerco policial alcanza su máxima expresión. Pero, como ha mostrado Foucault (2000), el rostro más sutil, el menos visible y el más interesante del poder no es la consabida función destructora o represiva del mismo, sino precisamente su capacidad para modelar los cuerpos, las emociones, las pulsiones aparentemente más espontáneas y las teorías más sofisticadas; el signo del poder es su productividad. Desde aquí, cobra pleno sentido aquel extraordinario dispositivo al que antes hacíamos referencia, desplegado a raíz del suceso que convulsionó la escena pública francesa de mediados de siglo. La larga retahíla de misas, novenas, mandamientos es tan solo una ínfima parte del aparato tecnológico que constituye el acontecimiento, de la respuesta oficial al atentado. Ante todo la sentencia es clara: la muerte del soberano es impensable, menos aún como una suerte de réplica, como una consecuencia de la mala gestión gubernamental. Damiens es reducido al silencio, no solo por las autoridades encargadas de la gestión del caso. Evidentemente aquellas declaraciones en las que manifestaba que nunca tuvo la intención de matar a Luis XV no redujeron un ápice la condena establecida de antemano, como tampoco le valió de nada la carta que escribió implorando clemencia a Su Majestad la madrugada del siete al ocho de enero (Le Breton, 1757: n. 56-58, p. 66a) ${ }^{6}$. La reiterada respuesta a los interrogatorios fue tomada por los jueces por una imperdonable frivolidad, $y$ Voltaire, entre otros, no podía dejar de asombrarse de que un individuo de tal calaña hubiera cometido la osadía de dictar una misiva destinada al monarca (Voltaire, 1997a: 221 ${ }^{7}$. En vano protestó Damiens cuando supo que iba a ser trasladado a la Conciergerie, desde donde le sería definitivamente imposible cumplir con su cometido, que, según confesaba, no era otro que hablar al rey, para advertirle acerca del peligro que corrían su vida y la del delfín si no reconducía la situación.

5. En la segunda mitad del siglo, crecen de manera exponencial los espías o mouchards - denominados mouches («moscas») por la población - , avivados sin duda por las nuevas reglamentaciones que intentan a toda costa limpiar la ciudad de mendigos, pobres y vagabundos, en particular la Ordenanza Real del 12 de noviembre de 1749, en la que «Su Majestad ordena que todos los mendigos, vagabundos y holgazanes, gente vulgar, que sean encontrados, sea en las calles de París, sea en las iglesias o a la puerta de dichas iglesias, sea en el campo o alrededores de París, de cualquier edad o sexo que puedan ser, sean arrestados y conducidos a las prisiones, para permanecer allí tanto tiempo como se juzgue necesario» [ «Sa Majesté ordonne que tous les mendiants, vagabonds et gens sans aveu, généralement quelconques, qui seront trouvés, soit dans les rues de Paris, soit dans les églises ou à la porte desdites églises, soit dans la campagne et aux environs de Paris, de quelque âge ou sexe qu'ils puissent être, soient arrêtés et conduits dans des maisons de force, pour y demeurer tant et si longuement qu'il sera jugé nécessaire»] (citado por Romon, 1983: 57).

6. Interrogatorio del nueve de enero.

7. «Damiens escribe al rey!, ¡un asesino escribe a quien había asesinado! Su carta es insensata y conforme a la abyección de su estado» [ «Damiens écrit au roi !, un assassin écrit à celui qu'il avait assassiné ! Sa lettre est insensée et conforme à l'abjection de son état»].

Ediciones Universidad de Salamanca / అ@@ Stud. his., H. ${ }^{a}$ mod., 43, n. 2 (2021), pp. 339-368 
No solo le debía ser negada a Damiens la posibilidad de acceder al soberano, sus palabras habían de morir entre las cuatro paredes donde se sucedían los interrogatorios. La empresa no era nada fácil: ante todo durante los escasos tres meses que van del atentado al suplicio, el público devora incansable cualquier noticia o relato que tenga que ver con el enigmático regicida y la no menos enigmática instrucción del caso: «Hay cien cuentos sobre la persona de este miserable que todavía no se conocen. Sus respuestas son tan vagas y contradictorias que no sabemos qué pensar», afirma la Gazette d'Amsterdam el 18 de enero ${ }^{8}$. «La curiosidad por lo que respecta a Damiens no está más satisfecha hoy que al comienzo del proceso», leemos en el Courrier d'Avignon el 25 de marzo'. Sin duda esta curiosidad es alimentada por el secreto de la instrucción, hasta tal punto que las autoridades, tras numerosos y enconados debates, optaron finalmente por publicar la totalidad del proceso unos meses más tarde (Le Breton, 1757). Para cuando este vio la luz, a últimos de mayo, el trabajo en cierta medida ya estaba hecho, si bien la versión difundida no había logrado convencer ni mucho menos a la totalidad de la población: aquí y allá, las declaraciones de los mandatarios y las palabras de Voltaire, la Gazette de France y los periódicos extranjeros habían presentado el frustrado regicidio como un suceso extraordinario perpetrado por un «fanático», un «miserable», un «monstruo», que no guardaba ninguna relación con las tensiones que sacudían el país. Damiens estaba loco, y sus palabras no eran dignas de ningún crédito, de hecho sus respuestas podían incriminar a todos los actores de la convulsa escena política: a los jesuitas ${ }^{10}$, a los jansenistas ${ }^{11}$, a los parlamentarios que recientemente habían presentado su dimisión por sus diferencias irreconciliables respecto a la Corona. Durante todo el proceso se realizó un esfuerzo encomiable con el fin de hacer aparecer a Damiens como un individuo absolutamente aislado, la prueba inequívoca de que los malos discursos - escuchados en las casas de los señores donde había servido el «execrable» regicida o leídos en las publicaciones clandestinas - podían acarrear consecuencias nefastas si llegaban a manos u oídos de una naturaleza viciada, enferma desde su nacimiento ${ }^{12}$.

8. «On fait cent contes sur la personne de ce misérable qu'on ne connaît point encore. Ses réponses sont si vagues et si opposées les unes aux autres qu'on ne sait qu'en penser.»

9. «La curiosité sur ce qui regarde Damiens n'est pas plus satisfaite aujourd'hui, qu'elle l'étoit au commencement de ce procès.»

10. La teoría del legítimo tiranicidio del español Juan de Mariana - cuyo libro De rege et regis institutione (1599) fue quemado en 1610 por el parlamento de París tras el asesinato de Enrique IV - alimentaba la desconfianza hacia los jesuitas.

11. El mencionado libro del Padre Quesnel, que portaba Damiens cuando hirió a Luis $\mathrm{XV}$, avivó las sospechas sobre los jansenistas.

12. «Malos discursos» (manvais discours o mauvais propos): la etiqueta corresponde a una rúbrica policial que cubre un amplio abanico de delitos, tales como injurias, crímenes de lesa majestad, complots contra el rey, denuncias de falsos complots, amenazas contra la Corona,

Ediciones Universidad de Salamanca / 요 Stud. his., H. ${ }^{a}$ mod., 43, n. 2 (2021), pp. 339-368 
Es cierto que las intrigas con todo no desaparecen, más allá incluso del espectáculo público de la Place de Grève. El nueve de marzo, el duque de Crö̈ llega a proponer una campaña de prensa con el fin de intentar convencer de una vez por todas a los súbditos de que el atentado no responde a ningún tipo de complot contra la persona real ni debe aguardarse el desenmascaramiento de los cómplices encubiertos: «Habría que ganarse a los periodistas y a quienes llevan la voz cantante para, poco a poco, preparar a los espíritus para creer que no hay cómplices» (Crö̈-Solre, 1906-1907: vol. I, p. 389 $)^{13}$. El argumento, desde luego, no satisfacía a Pierre-Jean Grosley -ni a la gran mayoría de la población, según Charles Collé14 -, que dos días después volvió a la carga con un nuevo panfleto (tras las Réflexions sur l'attentat commis le 5 janvier contre la vie du roi, que vio la luz el cinco de marzo) titulado Lettre d'un patriote, où l'on rapporte les faits qui prouvent que l'auteur de l'attentat commis sur la vie du roi a des complices, et la manière dont on instruit son procès: aún con mayor vehemencia que en el texto anterior (publicados ambos como es obvio de manera clandestina, al igual que los dos restantes libelos que habrían de aparecer a finales de mes), Grosley arremete contra la lectura oficial que pretendía imponer el duque de Crö̈. Las conclusiones no dejan lugar a dudas:

1. Parece cierto que el asesino tiene cómplices, e incluso que no ha sido más que el desgraciado instrumento de una temible conspiración. 2. Según los hechos más notorios acaecidos en París, los Jesuitas son más que sospechosos de estar detrás de esta conspiración, incluso de haberla maquinado ellos mismos. 3. Parece que algunos de los Informadores y otros Jueces no se han ocupado más que de descartar todo aquello que podría conducir a obtener la prueba jurídica de estos hechos $\left(\right.$ Grosley, 1757: 36-37) ${ }^{15}$.

predicciones astrológicas malvadas o malintencionadas... Como vemos, las infracciones contenidas bajo este epígrafe son de muy diversa índole y de distinta gravedad.

13. «Je représente qu'il faudrait gagner les gazetiers et les gens qui donnent le ton pour, petit à petit, préparer les esprits à croire qu'il n'y a pas de complice».

14. «Excepto las gentes de la corte que ocupan puestos o cargos y empleos, nadie puede convencerse de que este criminal no forme parte de un complot ni tenga cómplices [...] El proceso ha sido instruido de tal modo que como mínimo ha sido la causa de todos los rumores que corren» [«excepté les gens de la cour qui y tiennent ici des places ou des charges et des emplois, personne ne peut se mettre dans l'esprit que ce criminel soit sans complot et sans complices (...) Le procès a été instruit d'une façon qui a été au moins la cause de tous les bruits qui courent»] (Collé, 1868: vol. II, p. 81).

15. «1. Il paroît certain que l'assassin a des complices, et qu'il n'a même été que le malheureux instrument d'une redoutable conspiration. 2. Les faits les plus notoires à Paris rendent les Jésuites plus que suspects d'avoir été dans cette conspiration, ou même de l'avoir formée. 3. Il semble que quelques-uns des Rapporteurs et des autres Juges ne soient occupés qu'à écarter tout ce qui pourroit conduire à acquérir la preuve juridique de ces faits.» La Lettre d'un patriote forma parte de Les iniquités déconvertes, donde figura Londres como lugar de publicación,

Ediciones Universidad de Salamanca / 요 Stud. his., H. ${ }^{a}$ mod., 43, n. 2 (2021), pp. 339-368 
Grosley despliega todo su arsenal retórico para intentar probar sus tres argumentos, que, como reconoce el propio autor, son esgrimidos por buena parte de sus compatriotas, quienes también se ensañan ante todo con la Compañía de Jesús:

Se aprecia como una continuación de este asesinato [leemos en la Gazette de Cologne del 25 de enero] un diluvio de Piezas, Escritos y Versos sediciosos del que estamos inundados. Hay carteles por todas partes. Los Conventos mismos no se salvan. Los Jesuitas los sufren particularmente. Se han encontrado carteles en las puertas de sus Colegios donde aparecen en grandes caracteres las palabras siguientes: Vecinos desalojados, si no queréis ser quemados ${ }^{16}$.

Las intrigas y suposiciones, decíamos, son frecuentes tras el atentado, y continúan más allá del suplicio del criminal. Pero el trabajo realizado con el fin de imponer una interpretación al menos tolerable no resulta en absoluto infructuoso. El citado fragmento de la Gazette de Cologne es de hecho una de las pocas ocasiones en que un periódico comenta con tal lujo de detalles una realidad sin duda conocida por todos: las palabras sediciosas han tomado las calles de París. Si queremos ejemplificar la postura que asume la prensa respecto al caso Damiens, basta la sentencia del Courrier d'Avignon del ocho de abril:

No es más que el asesino del Rey y de un Rey extremadamente querido por sus pueblos, que podamos verlo sufrir todo lo que este miserable ha sufrido, sin que la compasión por sus dolores combata ni supere el horror de su crimen ${ }^{17}$.

Más allá de la monstruosidad del crimen y las alabanzas del Bien Amado, los periódicos guardan silencio. Raras veces se menciona la otra cara del fenómeno, y si

aunque el texto se editó realmente en París (se trata obviamente de una maniobra para intentar burlar con mayor facilidad la censura). Les iniquités déconvertes es una compilación de los cuatro panfletos de Grosley que aparecieron el mes de marzo - junto con los dos ya citados, la Déclaration de guerre contre les auteurs du parricide (22 de marzo) y la Lettre d'un solitaire, sur le Mandement de M. l'Archevêque de Paris (27 de marzo) - . En los registros del Parlement civil hallamos la orden del 30 de marzo, en virtud de la cual fueron quemados los tres primeros libelos publicados por Grosley. La sentencia prohíbe además «a todos los Libreros, Impresores, vendedores ambulantes y a todos los demás imprimir, despachar o distribuir de cualquier otra manera bajo pena de castigo corporal» [«à tous Libraires, Imprimeurs et colporteurs et à tous autres de les imprimer, rendre débiter ou autrement distribuer quelque manière que ce puisse être sous peine de punition corporelle»] (Archives Nationales, $\mathrm{X}^{1 \mathrm{~A}}$ 8497, fo 217-220).

16. "On regarde comme une suite de cet assassinat un déluge de Pièces, d’Écrits et de Vers séditieux dont nous sommes inondés. On en affiche par tout. Les Couvents mêmes ne sont pas épargnés. Les Jésuites en souffrent particulièrement. On a trouvé affichés aux portes de leurs Collèges en gros caractères les mots suivants: Voisins délogés, si vous ne voulez pas être brûlés.»

17. «Il n'y a que l'assassin du Roi et d'un Roi extrêmement chéri de ses peuples, que l'on puisse voir souffrir tout ce que ce misérable a souffert, sans que la compassion de ses maux combatte et même surmonte l'horreur de son crime.»

Ediciones Universidad de Salamanca / @®@@ Stud. his., H. ${ }^{a}$ mod., 43, n. 2 (2021), pp. 339-368 
se alude a esta, a los malos discursos, no es sino para criticarlos severamente o para celebrar el arresto de los responsables de los escritos subversivos. La conclusión vale tanto para la Gazette de France como para las gacetas extranjeras, que soportan en menor medida los rigores de la censura monárquica.

La única excepción realmente significativa de esta regla la constituye la Gazette de Leyde del diez de enero de 1757: tras subrayar la atrocidad del atentado que ha puesto en peligro la vida del monarca, recuerda a los bandidos Cartouche y Mandrin - es el único periódico que se atreve a citar Le testament politique de Louis Mandrin, uno de los panfletos clandestinos que vieron la luz tras la ejecución de este héroe popular en 1755 (Mandrin, 1976) - , cuyas acciones muestran a los soberanos «las debilidades de su Gobierno» ${ }^{18}$. Es necesario, leemos en la Gazette de Leyde, dejar de observar la actualidad «como se ve la lluvia y el buen tiempo» ${ }^{19}$, tomar distancia, conocer en fin la historia, pues esta es

una regla de comparación que fija y rectifica nuestras ideas acerca de los acontecimientos actuales; y que nos predispone para desde el pasado juzgar con garantías no solo el presente, sino también el porvenir ${ }^{20}$.

Sobre Damiens, reiteramos, se ha impuesto el silencio. La excepción no tiene fuerza para subvertir la regla, pero tiende a mostrar la tremenda complejidad del problema. No por casualidad la apelación a la historia y a la literatura clandestina (por cierto, el panfleto sobre Mandrin no volverá a ser citado) viene de manos de la prensa extranjera, no por casualidad se trata, concretamente, de la Gazette de Leyde, cuyo editor, Etienne Luzac, en una carta remitida en 1772 al embajador francés en Holanda protestará contra las fuertes presiones de la administración de Versalles: si el periódico, como pretenden las autoridades galas, ha de limitarse a las noticias oficiales,

el público francés notaría esta reticencia, que produciría el efecto contrario al esperado... Entonces, Señor, en ese caso, ¿qué credibilidad daría usted a mi gaceta? ¿Qué credibilidad tendría para aquellos que simplemente quieren conocer el estado actual de los acontecimientos mundiales? (Luzac citado por Popkin, 1987: 210)21.

18. «Des endroits faibles de leur Gouvernement.»

19. «Comme on voit la pluie et le beau temps.»

20. «Une règle de comparaison qui fixe et rectifie nos idées au sujet des événements présents; et qui nous met en état d'après le passé de juger sûrement non seulement du présent mais de l'avenir.»

21. "The French public would notice this reticence, which would produce the opposite effect from what is expected... Now, Sir, in that case, what respect would you give my gazette? What respect would it have left among those who simply want the present state of the world's affairs?».

Ediciones Universidad de Salamanca / అ@@ Stud. his., H. ${ }^{a}$ mod., 43, n. 2 (2021), pp. 339-368 
La Gazette de Leyde o la Gazette d'Amsterdam - las dos gacetas extranjeras más importantes de la época, manifiestamente pro-parlamentarias ${ }^{22}-$ no pueden ser consideradas como prensa subversiva, a pesar de que se desmarquen de manera nítida de la línea editorial de la Gazette de France, la propaganda oficial del régimen, cuya narración profundamente apolítica de los acontecimientos de la corte satisfacía cada vez menos las exigencias de los lectores franceses. Las publicaciones extranjeras, por tanto, no se pliegan por completo a las directrices gubernamentales, pero es difícilmente sostenible asimismo la hipótesis opuesta; las gacetas no disfrutan sino de una independencia relativa, que traduce un juego de disimulación que acaba favoreciendo a las dos partes: a los periódicos, que aseguran así su circulación y su éxito en el reino; al gobierno, concluye Jeremy Popkin (1987), que prefiere que el público crea que la prensa extranjera no es controlada por la monarquía.

\section{3. «YO ME HE SACRIFICADO POR EL PUEBLO»}

Los panfletos de Grosley no forman parte de este juego de disimulación, pero, al igual que las terribles acusaciones que se lanzan unos contra otros los jesuitas y los jansenistas, sus escritos no logran alcanzar el sentido (y el sentir) más profundo del testimonio de Damiens: «Ha dicho - constatan los jueces - que era [que había abordado al rey] porque las tres cuartas partes del pueblo perecían de miseria», «que lo que había hecho, lo había hecho por el pueblo..., que había cometido ese acto por el triste estado al que se había reducido al pueblo», «que había quedado impresionado por los rumores que contaban lo que el Parlamento había hecho, por las quejas del pueblo de París», "que le había afectado extremadamente ver al pueblo de París vender todo lo que tiene para vivir y subsistir» (Damiens citado por Thelliez, 2002, 89) ${ }^{23}$. «Yo me he sacrificado por el pueblo», concluye Damiens (citado por Thelliez: 2002: 49) ${ }^{24}$.

La palabra más repetida del acusado no aparece en las publicaciones clandestinas de Grosley, y tampoco en la prensa. Son otros los que recogen el testigo de Damiens: en París, sobre todo, pero también en Normandía, en Clermont-Ferrand,

22. Si bien la Gazette de Leyde tomó la delantera en los últimos decenios del Antiguo Régimen, la Gazette d'Amsterdam, que vivió sus años dorados desde comienzos de siglo hasta la Regencia (fue durante algún tiempo la publicación favorita de los jansenistas), jugó un papel muy importante durante las crisis parlamentarias de mediados de siglo (Rétat, 2001: 187-209).

23. "A dit que c'était parce que les trois quarts du peuple périssaient de misère», "que ce qu'il avait fait, il l'avait fait pour le peuple... qu'il avait été déterminé par le triste état où est réduit le peuple», "qu'il avait été frappé des bruits de ce que le Parlement avait fait, des plaints du peuple de Paris», "qu'il a été extrêment touché de voir le peuple de Paris vendre tout ce qu'ils ont pour pouvoir vivre et subsister».

24. «Je me suis sacrifié pour le peuple». 
en Mayenne, numerosos súbditos lamentan que el regicidio no se haya consumado y declaran que ellos habrían corrido mejor suerte: «Yo me habría ensañado con el corazón del sagrado cabrón», confiesa François Bellier de la Chauvellais, un aprendiz de curtidor en un cabaret cercano a Château-Gontier; "yo le habría taladrado las tripas con una lezna», profiere un campesino en otro cabaret cerca de Gisors (Van Kley, 1984: 247). Según Dale Kenneth Van Kley (1984: 246 y ss.), hay aproximadamente 25 casos similares denunciados a las autoridades entre 1757 y 1758 . En septiembre de este último año una carta recibida por Mopinot de la Chapotte testimonia la avalancha de carteles sediciosos suscitados por el caso Damiens:

Desde la ejecución de Moriceau, los carteles más infames se renuevan cada noche, a las puertas de las iglesias, en los lugares donde se hace justicia; en el Louvre, en el Palais Royal. Se evoca constantemente la sombra de Damiens, el mejor de los reyes es calificado con títulos odiosos; se reprocha a los Franceses su cobardía; semejantes escritos adelantaron la muerte del César ([Mopinot de la Chapotte], 1905: 232-233) 25 .

Son estos carteles incendiarios, estos hombres y mujeres del petit peuple los que mejor han comprendido al «loco» parricida: Gadibois, obrera, acusada «de haber dicho, hablando del asesinato que Damiens había cometido, que este había hecho bien, y que si ella se encontrara con el Rey frente a frente, actuaría de la misma forma» (F. Ravaisson-Mollien, 1891: 8) ${ }^{26}$; Avecque, sombrerero, que en el segundo interrogatorio al que fue sometido dijo que «Ravaillac tenía sus razones cuando apuñaló a Enrique IV», y que, al igual que Damiens, habría logrado escapar si

25. «Depuis l'exécution de Moriceau, les placards les plus infâmes se renouvellent chaque nuit, aux portes des églises, aux lieux où l'on rend la justice; au Louvre, au Palais Royal. On évoque l'ombre de Damiens, le meilleur des rois est qualifié de titres odieux; on reproche aux Français leur lâcheté; de semblables écrits hâtèrent la mort du César». Se trata de la carta XCII, fechada el 18 de septiembre de 1758. La misiva continúa lamentando las tristes condiciones en que vive la población, auténtico caldo de cultivo de los manvais discours: «Desgraciadamente los espíritus sediciosos tienen demasiados motivos para quejarse de la suerte del pueblo. El número de impuestos que se suceden enajena los espíritus; el nuevo tributo implantado en las ciudades reduce las provincias a la mendicidad; la agitación se expande en todos los espíritus; el pan aumenta cada día de mercado; se espera un incremento sobre el vino, la leña, la sal, las velas.» [«Malheureusement les esprits séditieux n'ont que trop sujet de plaindre la sort des peuples. Le nombre d'impôts qui se succèdent aliène beaucoup les esprits; le nouvel octroi mis sur les villes réduit les provinces à la mendicité; la fermentation se répand dans tous les esprits; le pain augmente, chaque jour de marché; on s'attend une augmentation sur le vin, le bois, le sel, la chandelle.»]

26. «D'avoir dit, en parlant de l'assassinat que Damiens avait commis, qu'il avait bien fait, et que si elle trouvait le Roi entre 4 yeux, elle en ferait autant» (nota del 18 de septiembre de 1757).

Ediciones Universidad de Salamanca / @®@@ Stud. his., H. ${ }^{a}$ mod., 43, n. 2 (2021), pp. 339-368 
hubiera querido (F. Ravaisson-Mollien, 1891: 16) ${ }^{27}$; Paumier, criado como Damiens, para quien este «debía ser un gran santo del paraíso» (F. Ravaisson-Mollien, 1891: 139) ${ }^{28}$. Para Gadibois, Avecque, Paumier y tantos otros, Damiens era alguien cercano, todos ellos fueron encerrados en la Bastilla por haber aplaudido la osadía del frustrado regicida.

Además, la sombra de este no se desvanece con el paso del tiempo, como prueba la misiva destinada a Mopinot de la Chapotte, la cual hacía referencia a la aplicación de la sentencia contra Mauriceau de la Motte, un oficial notificador del Palacio de Justicia que, durante una cena en un restaurante de la Rue Saint-Germainl’Auxerrois, a propósito del caso Damiens «habló con arrebato sobre la manera como el proceso había sido instruido, contra el gobierno, incluso contra el rey y los ministros» (Barbier, 1857-1866: vol. VII, p. 89) ${ }^{29}$. Presunto autor de palabras sediciosas y atentatorias contra la autoridad real (Barbier, 1857-1866: vol. VII, p. $90)^{30}$ - fueron hallados en su domicilio carteles que empapelaron algunos lugares de París antes y después del atentado de 1757, sin muestras de que dichos carteles hubieran sido arrancados, tal y como defendía el acusado-, Mauriceau de la Motte fue ahorcado en la Place de Grève en septiembre de 1758.

Había una gran multitud a su paso y en la Place de Grève [anota Barbier (1857-1866: vol. VII, p. 91) en su Journal]. Algunos decían que no se da muerte por palabras o por simples escritos; otros esperaban que se le concediera el indulto; pero se quiso dar ejemplo con un burgués de París, que desempeñaba un cargo, para reprimir los abusos de un gran número de fanáticos, que hablan con demasiado atrevimiento del gobierno ${ }^{31}$.

La narración del abogado Barbier no deja lugar a dudas. «El dispositivo se atasca», concluye Roger Chartier (2003: 132): el castigo público y ejemplar ya no obtiene el efecto deseado; el sobrepoder monárquico, argumenta Michel Foucault, resulta cada vez más inquietante a los ojos de una multitud que protesta contra la desproporción entre el delito y el castigo, que aclama las irreverencias del criminal

27. «Ravaillac avait ses raisons quand il a poignardé Henri IV» (nota del 10 de marzo de 1757).

28. «Devait être un grand Saint du paradis» (nota del 20 de junio de 1758).

29. «Il a parlé avec emportement sur la manière dont ce procès a été instruit, contre le gouvernement, même contre le Roi et les ministres».

30. Auteur des propos séditienx et attentatoires à l'autorité royale, tal era el lema que se exhibía en los carteles que rodeaban el cuerpo del condenado durante el suplicio.

31. «Il y avoit dans son passage et à la Grève grande affluence de peuple. Quelques-uns disoient qu'on ne fait point mourir pour des paroles et des simples écrits; d'autres espéroient qu'il auroit sa grâce; mais on a voulu faire un exemple sur un bourgeois de Paris, homme ayant une charge, pour réprimer la licence d'un nombre de fanatiques, qui parlent trop hardiment du gouvernement».

Ediciones Universidad de Salamanca / @®@@ Stud. his., H. ${ }^{a}$ mod., 43, n. 2 (2021), pp. 339-368 
convertido en héroe (Foucault, 2000: 65) 32. El ceremonial que representa la politica del terror (Foucault, 2000: 54) se anuda a los conflictos sociales y el imaginario colectivo, subraya Arlette Farge (1994: 219), y, lejos de convocar la adhesión acrítica de los súbditos al acto supremo de justicia, evoca respuestas y alianzas insospechadas (Cases, 2006: 3).

Como cabía esperar, un año y medio antes de la controvertida ejecución de Mauriceau de la Motte, tampoco el suplicio de Damiens se desarrolló sin contratiempos. Soubise, uno de los dieciséis verdugos dispuestos para ajusticiar al reo, estaba borracho y no se había acordado de comprar azufre, cera, resina, plomo, los ingredientes indispensables para llevar a cabo la sentencia. Abarrotada de espectadores, la Place de Grève comenzaba a clamar contra la ineficiencia de los verdugos, y el jefe de los mismos, Gabriel Sanson, el exécuteur des hautes œuvres de París, ordenó a los criados que compraran los materiales necesarios; pero la mayoría de los comerciantes de la zona, como buena parte del pueblo llano, simpatizaban con el regicida y se negaron a vender los componentes que, al cabo de una hora, empezaron a fundirse en los calderos, ante la atenta mirada del público que llenaba no solo la plaza, sino también las habitaciones con vistas a la ceremonia, que se alquilaban a precios desorbitados (Blom, 2007: 254-255).

Como advertíamos antes, los ecos de Damiens perdurarán en el tiempo. En 1762, cuando Paul-René du Truch de la Chaux, guardia real, fue arrestado por simular un enfrentamiento con dos individuos que presuntamente intentaban matar al rey, buena parte de las conversaciones registradas por los agentes policiales recuerdan el fallido atentado de 1757:

Unos [afirma un oficial, tras visitar los cafés de Dubuisson y de Bigorne, cerca de la Comédie Française] dicen que el guardaespaldas herido fue el primero que echó el guante al desgraciado Damiens, en el momento en que este cometió su horrible crimen, razón por la cual Su Majestad le acordó una pensión, y que, deseoso de aumentar su fortuna, había inventado la indigna estratagema de propinarse, a sí mismo, varias puñaladas (F. Ravaisson-Mollien et L. Ravaisson-Mollien, 1903: 192) ${ }^{33}$.

32. El sistema se reajusta, escribe Foucault, y aquellas prácticas punitivas que culminaban en el ritual político-jurídico de la Place de Grève serán sustituidas por un conjunto de dispositivos disciplinarios que ya no tienen por objeto el cuerpo del supliciado, sino el «alma» del delincuente.

33. «Les uns disent que le garde de corps blessé est celui qui, le premier, mit la main sur le malheureux Damiens, au moment qu'il eut commis son crime horrible, pour raison de quoi S. M. lui a accordé une pension, et que, désirant augmenter sa fortune, il avait inventé l'indigne stratagème de se porter, lui-même, plusieurs coups de poignard» (nota del nueve de enero de 1762).

Ediciones Universidad de Salamanca / @®@@ Stud. his., H. ${ }^{a}$ mod., 43, n. 2 (2021), pp. 339-368 
Se trata de una de las tres versiones del suceso, que es interpretado también como una disputa en el hostal del guardia entre este y dos particulares que querían que el agente les facilitara el acceso al soberano; y ofrece asimismo la oportunidad de renovar las teorías conspirativas que apuntan a los jesuitas.

Las lesiones que se infligió La Chaux le costaron demasiado caras, el uno de febrero de 1762 fue condenado a la horca. Es el precio a pagar por haber reactivado el temible imaginario de la muerte del rey, que, junto a Châtel, Clément o Ravaillac ${ }^{34}$, registra desde 1757 el nombre de Damiens, quien permaneció en la memoria (y no solo en la memoria) a pesar de que las autoridades intentaran por todos los medios eliminar cualquier rastro del criminal: su cuerpo, tras ser supliciado, fue reducido a cenizas y estas fueron arrojadas al viento; la casa donde nació fue demolida; su padre, Pierre-Joseph Damiens, su mujer, Élisabeth Molerienne, y su hija, MarieÉlisabeth Damiens, fueron expulsados del reino, y el resto de la familia se vio obligada a cambiar de apellido (Arrêt de la Cour de Parlement contre Robert-François Damiens..., 1757) $)^{35}$.

\section{UNA CRISIS POLÍTICA DE LARGA DURACIÓN}

Sin lugar a dudas, el caso Damiens, escribe Dale Kenneth Van Kley (1984: 253), «revela que en 1757 los mawvais discours populares afectaban a la monarquía directamente» ${ }^{36}$. El fenómeno no es muy anterior a esta fecha, afirma a continuación Van Kley, quien subraya a este respecto la tremenda importancia de la década de 1750.

Con todo, no obstante la violenta excepcionalidad del fallido atentado contra Luis XV, tal vez resulte adecuado inscribirlo en un contexto más amplio, no para cuestionar la enorme trascendencia del suceso que convulsionó la escena pública francesa a comienzos de 1757, sino para hacernos cargo de la significación de un acontecimiento que se destaca como tal precisamente en la medida en que se revela como una suerte de culminación de una serie de dinámicas de mayor recorrido

34. «¿Quién podría creer que en un siglo tan ilustrado como el nuestro volveríamos a contemplar las espantosas escenas, los detestables crímenes de los Cléments, Châtels, Ravaillacs, nombres que no somos capaces de pronunciar sin estremecernos de horror?» [«qui auroit pu croire que dans un siècle aussi éclairé que le nôtre on renouvellaît les scènes affreuses, les détestables forfaits des Cléments, des Châtels, des Ravaillacs, noms qu'on ne sauroit prononcer sans frémir d'horreur?»] ([Gazette d'Amsterdam], 14 de enero de 1757).

35. Este arrêt, del 26 de marzo, contempla la demolición de la casa donde nació Damiens, que fue conducido dos días después a la Place de Grève. Al día siguiente se aprobaron las disposiciones respecto a su familia (Arrêt de la cour de Parlement contre la famille de RobertFrançois Damiens, 1757).

36. «Reveals that by 1757 the popular manvais discours was affecting the monarchy directly».

Ediciones Universidad de Salamanca / 
histórico, en la medida en que es capaz de sacar a la luz una problemática que gracias a su radical visibilidad obtiene ahora pleno reconocimiento. El propio Van Kley, en Los orígenes religiosos de la Revolución Francesa, publicado en 1996 (traducido al castellano en 2002), matizaba en cierto modo la hipótesis que adelantaba en aquel libro de 1984 que citamos más arriba, The Damiens Affair and the Unraveling of the Ancien Régime, 1750-1770. En el texto de 1996 el autor se hace eco de la crítica de Arlette Farge (1992: 256) y reconoce que las manifestaciones sediciosas antimonárquicas de 1757 son menos novedosas de lo que sospechaba cuando compuso el monográfico sobre el caso Damiens, que tal vez no le concedió la suficiente importancia a las prácticas contestatarias que según Arlette Farge subieron de tono de manera considerable desde finales de la década de 1720 (Van Kley, 2002).

La historiadora francesa llama así la atención sobre la ofensiva lanzada en 1728 por el cardenal Fleury, ministro de Luis XV, contra los clérigos que apelaron ante la bula Unigenitus, y recuerda a renglón seguido el importante papel que jugó el diácono Pâris, que murió en 1727 a la edad de 37 años, tras haberse destacado tanto por la firme lucha que mantuvo contra la bula como por su dedicación a los pobres, a quienes legó todos sus bienes. François de Pâris se convirtió, como escribe Farge (1992: 44), en «la imagen emblemática y mítica del eclesiástico jansenista del siglo XVIII ${ }^{37}$, tanto es así que sobre su tumba, en el cementerio de Saint-Médard, se sucedieron numerosos milagros, hasta que una orden real fechada el 27 de enero de 1732 determinó el cierre del cementerio, que no volvió a abrir sus puertas hasta 1807. La clausura de Saint-Médard era la respuesta de la monarquía, que se vio desbordada ante la magnitud de un problema que escapaba al control ejercido a través de la vigilancia cotidiana del lugar donde a partir de entonces, como rezaba el pareado que recorrió París, quedaría terminantemente prohibido hacer milagros: «De par le Roi défense à Dieu / De faire miracle en ce lieu» - «De parte del Rey se prohíbe a Dios / Hacer milagros en este lugar» - (Zysberg, 2022: 153) [ilustración 1]. La ironía era la réplica popular ante un régimen que parecía reclamar el monopolio de las curaciones milagrosas, como el toque real practicado con los enfermos de escrofulismo.

Arlette Farge destaca también la decisiva aparición de las Nouvelles ecclésiastiques, el periódico que vio la luz el 23 de febrero de 1728 con el firme propósito de denunciar las numerosas persecuciones sufridas por los jansenistas desde la promulgación de la bula Unigenitus. Un precio económico, unos seis sous, y una tirada relativamente alta, alrededor de seis mil ejemplares, ayudan a explicar la extraordinaria difusión de una gaceta que hizo de la apelación a la opinión pública una de sus señas de identidad:

37. «L'image emblématique et mythique de l'ecclésiastique janséniste du XVIIIe siècle».

Ediciones Universidad de Salamanca / @®@@ Stud. his., H. ${ }^{a}$ mod., 43, n. 2 (2021), pp. 339-368 
Ilustración 1: Jean Restout le Jeune, «Le tombeau de François de Pâris». Grabado incluido en el libro de Louis Basile Carré de Montgeron, La Vérité des miracles opérés par l'intercession de M. de Pâris et autres apellans, démontrés contre M. l'archevêque de Sens, Utrecht, chez les Libraires de la Compagnie, 1737, vol. I. «Lo más escandaloso - señala uno de los agentes policiales - es ver a jóvenes bastante bellas y lozanas entre los brazos de hombres que, al socorrerlas, pueden satisfacer ciertas pasiones» (citado por Zysberg, 2002) ${ }^{38}$.

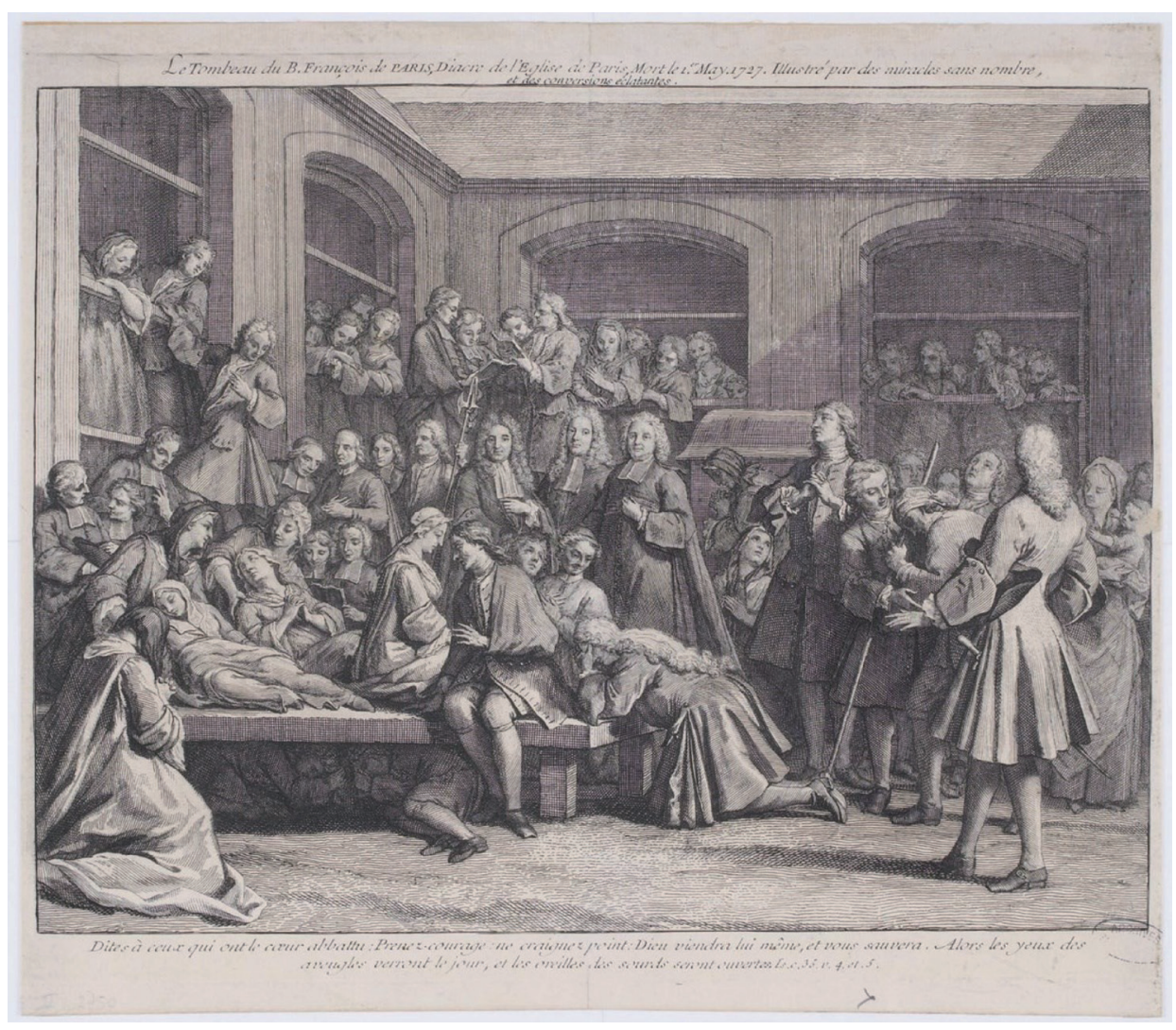

Fuente: Wikimedia Commons (dominio público).

38. «Ce qu'il y a de plus scandaleux c'est d'y voir des jeunes filles assez jolies et bien faites entre les bras des hommes, qui, en les secourant, peuvent contenter certaines passions». 
Cuando la bula Unigenitus apareció en 1713 [leemos en el primer número de las Nouvelles ecclésiastiques (citado por Farge, 1992: 65-66)], ya subsistían en la Iglesia grandes males, que no dejaban de aumentar desde hace siglos [...] Un gran número de eclesiásticos están empeñados en creer que no se trataba más que de la opinión de escuela que había que dejar para las discusiones de los teólogos... Que no convenía a los fieles tomar parte y ser instruidos... Hemos comprendido que el asunto era más serio... Se ha extendido universalmente el deseo de estar informados de lo que ha pasado... ¿Qué mejor que encontrar un medio a través del cual podamos llegar a presentar los hechos a los ojos del público? Es lo que llevamos a cabo mediante este breve escrito titulado Nouvelles ecclésiastiques ${ }^{39}$.

«A los ojos del público» («sous les yeux du public») y, como no podía ser de otra manera, bajo la atenta mirada también de las autoridades, que no dejaron de perseguir a los responsables del periódico desde que este comenzó a andar.

Dale K. Van Kley (2002: 267 y ss.) admite como decíamos las matizaciones de Arlette Farge, pero sostiene que, aun reconociendo la importancia de los malos discursos registrados a partir de 1728, sigue siendo igualmente válida la hipótesis según la cual la década de 1750 resulta crucial por lo que respecta a la política religiosa antijansenista de la monarquía, que alcanzó su máxima expresión cuando el nuevo arzobispo de París, Christophe de Beaumont, y otros prelados decidieron que en sus diócesis habrían de serle negados los últimos sacramentos a los enemigos de la bula Unigenitus. La llamada disputa de los billetes de confesión (el nombre que recibían los certificados que atestiguaban que el moribundo se había confesado por última vez con un sacerdote que había aceptado la bula) hizo estallar definitivamente las profundas resistencias acumuladas contra la Corona en los últimos decenios. El clima de opinión generado por el proyecto de Beaumont y compañía (el arzobispo de París es uno de los personajes más criticados por Damiens) no solo amplifica la fuerza contestataria manifiesta en aquel irónico pareado a raíz del cierre de SaintMédard, sino que supone un notable salto cualitativo en cuanto al modo como se ejerce la crítica: como recuerda Arlette Farge (1992: 86), las Nouvelles ecclésiastiques ya no se comportan como en 1730 , no se limitan a denunciar la persecución de la causa jansenista, sino que lanzan abiertamente un alegato a favor de la conciencia

39. «Lorsque la bulle Unigenitus a paru en 1713, il y avait déjà dans l'Église de grands maux subsistants, et qui allaient toujours en croissant depuis siècles [...] Un grand nombre d'ecclésiastiques se sont obstinés à croire qu'il ne s'agissait que d'opinion d'école qu'il fallait laisser à discuter entre les théologiens... Qu'il ne convenait pas aux fidèles d'y prendre part et d'en être instruits... On a compris que l'affaire était plus sérieuse... On a désiré universellement d'être informé de ce qui se passait... Que pouvait-on faire de mieux que de trouver un moyen par lequel on pût parvenir à mettre les faits sous les yeux du public ? C'est qu'on exécute par ce petit écrit intitulé Nouvelles ecclésiastiques».

Ediciones Universidad de Salamanca / @®@@ Stud. his., H. ${ }^{a}$ mod., 43, n. 2 (2021), pp. 339-368 
individual, que en determinados casos - como el de los billets de confession - ha de oponerse a las directrices monárquicas.

La novedad subrayada por la autora de Dire et mal dire, el llamamiento del controvertido periódico jansenista a la razón del alma, tan soberana como el príncipe soberano, nos invita a reflexionar sobre otra hipótesis de trabajo, la desarrollada por Reinhart Koselleck en Crítica y crisis del mundo burgués:

A través del orden político que creó y organizó el Estado al pacificar el ámbito geopolítico devastado por las guerras civiles religiosas, creó también los presupuestos para el desarrollo del mundo moral [...] La separación entre moral y política, consumada una vez por el Estado, se vuelve ahora contra éste, por cuanto que se ve forzado a someterse al proceso acusatorio moral por el acto que consistió en la constitución de un ámbito dentro del cual se sobrevivió a sí mismo (Koselleck, 1965: 21-22).

Como pone de manifiesto la problemática jansenista, la estrecha vinculación entre la interioridad moral y las prácticas contestatarias es una de las claves de la crítica y crisis del absolutismo, que de esta forma, argumenta Koselleck, cavó su propia tumba, desde el momento en que, al escindirse de la razón de Estado, la moral quedó relegada al ámbito puramente privado, con lo que conquistó la autonomía suficiente para enjuiciar en virtud de esta el comportamiento del régimen político.

La lectura de Crítica y crisis parece bastante convincente; pero no dejan de aparecer ciertos problemas al analizar las tesis de Koselleck a la luz del conflicto jansenista, cuya extraordinaria capacidad para desestabilizar el Antiguo Régimen no se comprende como una deriva del proceso que conduce a la definitiva autonomía del Estado con respecto a la autoridad eclesiástica, no proviene de la exacerbación de la máxima cuius regio eius religio (la confesión religiosa del monarca se aplica a todos los súbditos del reino). Si la problemática jansenista golpeó duramente las entrañas del absolutismo sagrado fue porque este traicionó la lógica hobbesiana, o tal vez porque nunca logró aplicarla hasta sus últimas consecuencias, nunca consiguió vencer las viejas resistencias que provocaron que, once años más tarde, Luis XIV decidiera condenar la Declaración regalista de 1682, que establecía la total independencia del príncipe respecto al papa. La monarquía, que había registrado la polémica bula Unigenitus en 1714 aun contando con la desaprobación de una porción importante del clero, ya no logró rehacerse tras la llamada disputa de los sacramentos o de los billetes de confesión; había apostado tan fuerte por la bula papal que esta se había convertido en una de sus señas de identidad, a pesar de que no pocos advirtieron acerca de los conflictos que suscitaba dicha medida con respecto a los principios de la Iglesia galicana.

La línea interpretativa de Koselleck - quizá, en ocasiones, más el espíritu que la literalidad de la misma - sigue resultando muy rentable, pues apunta hacia una

Ediciones Universidad de Salamanca / 요 Stud. his., H. ${ }^{a}$ mod., 43, n. 2 (2021), pp. 339-368 
historia de larga duración que tiende a mostrar cómo algunas de las opciones estratégicas de las autoridades supuestamente incuestionables del Antiguo Régimen fueron minando paulatinamente su poderío. La profunda crisis de las últimas décadas del Ancien Régime no solo se explica a partir de los diversos discursos y prácticas que, desde uno u otro lugar, remueven los cimientos del viejo orden, sino que aun estas manifestaciones contestatarias pueden ser estudiadas al interior de las dinámicas de largo recorrido histórico que no pueden ocultar, sin embargo, la excepcionalidad de los nuevos acontecimientos, las importantes discontinuidades que han quedado cifradas a partir de 1750.

La «desacralización de la monarquía» - por retomar los términos de Van Kley y de Merrick (1990) - puede así estudiarse desde dentro. El frustrado regicidio de Luis XV y los numerosos ecos del mismo traducen en definitiva el profundo malestar de la población respecto de una realeza cuya representación se modificó ostensiblemente desde el traslado de Luis XIV a Versalles, lo cual significó, como ha señalado Ralph E. Giesey (1987), la definitiva sustitución del modelo renacentista de los ceremoniales de estado por la relativa privacidad de la sociedad cortesana, una suerte de continuum de la etiqueta alejado de la magnificencia de los antiguos rituales políticos, que lograban, por una parte, suspender el curso ordinario del tiempo y conseguían asimismo, mediante un acto publicístico de gran envergadura, involucrar a la población, que de este modo se sentía partícipe de una historia común. Las escasas apariciones públicas del Rey Sol provocaron que los súbditos se fueran alejando cada vez más del símbolo por excelencia de la nación, investido de atributos divinos. Su última entrada real en París data de 1660, la fecha de su matrimonio, y no asistió a una sesión solemne del Parlamento desde 1673.

A buen seguro, Luis XIV se equivocó al pretender que su nueva e imponente residencia versallesca habría de engrandecer aún más a un rey «que no se dejaba ver todos los días». Tal es, según Saint-Simon, una de las razones que impulsaron al monarca a abandonar la ciudad y refugiarse en el campo. Junto a este motivo, continúa Saint-Simon, la decisión se vio favorecida por otras circunstancias:

Los desórdenes que, durante su minoría de edad, se desarrollaron en París le habían hecho desagradable la ciudad. Más aún consideraba peligroso habitar allí; creyó dificultar las cábalas, si trasladaba el lugar de la corte. No menor influencia tuvo en su decisión también la economía de su amante y el cuidado de no escandalizar demasiado, viviendo en medio de una gran población (Saint-Simon citado por Elias, 1982: 263).

Las razones son muy numerosas, pero todas ellas, en definitiva, concluye Norbert Elias (1982: 263), apuntaban a una misma dirección, todas «giraban en torno de la conservación y del perfeccionamiento del poder y del prestigio» de un soberano que gustaba de alojar en Versalles a todos los miembros de la alta sociedad que así 
lo solicitaran, pues desde su nuevo emplazamiento podía vigilar muy de cerca los movimientos de una nobleza por la que siempre se había sentido amenazado.

A pesar de contar con una amplísima nómina de pintores, escultores, orfebres y escritores, la imagen de Louis le Grand - el protagonista, a juicio de Voltaire (1996), del último de los grandes siglos de la historia de la humanidad - no dejó de deteriorarse desde los últimos decenios del siglo XVII. Así como el traslado de la corte a Versalles aumentó la brecha entre la población y el monarca, la decadencia del mito de la Antigüedad (objeto de discusión durante la querella entre Antiguos y Modernos) y del modelo epistémico basado en las analogías y las equivalencias - agujereado por el emergente mecanicismo - hicieron oscilar las representaciones de la figura del soberano, estrechamente ligadas a una concepción mística del mundo que permitía naturalizar el poder político y dotar al príncipe de la autoridad y el prestigio de la tradición clásica, así como del carácter sagrado de la divinidad, puesto de manifiesto a través de la analogía simbólica que durante las ceremonias de coronación unía al gobernante y al mito solar, y continuamente reactualizado mediante el toque real, que lograba sanar o al menos aliviar a los enfermos (Burke, 2003: 122-126) ${ }^{40}$.

Para Roger Chartier (2003: 137-138), es más conveniente hablar de «desencanto» respecto a la monarquía, antes que de «desacralización» de la misma, pues los numerosos discursos que ensalzan la divinidad de los reyes no implican necesariamente la plena adhesión de los súbditos a la letra de tales enunciados. El historiador francés no deja de reconocer, evidentemente, que el reinado de Luis XIV supuso un punto de inflexión en cuanto al desapego de los súbditos ante un soberano que abandonó París y los rituales de Estado, pero prefiere fijar la destrucción del ceremonial público antes de la llegada al trono del Rey Sol. En 1610, el joven Luis XIII, todavía menor de edad, altera profundamente la lógica ritual al presentarse en una sesión solemne del Parlamento antes de que su predecesor, Enrique IV, fuera enterrado. El nuevo soberano irrumpe por tanto en escena cuando aún no se había consumado el funeral real, el cual mediante la disociación del cuerpo del monarca, la efigie de madera por un lado y el cadáver del difunto por otro, actualizaba la distinción simbólica entre el cuerpo político del rey, que nunca muere, y el cuerpo físico, al que se da sepultura. La precipitada asistencia de Luis XIII al Parlamento descomponía el orden de la tradición, según el cual el rey entrante, si bien ejercía como tal desde el

40. Ciertamente, el Rey Sol no dejó de practicar el toque real, si bien sustituyó la antigua fórmula, Le roi te touche, Dien te guérit (el rey te toca, Dios te cura), por un enunciado más prudente: Dieu te guérisse (que Dios te cure). El mito solar tampoco desapareció por completo de las representaciones monárquicas, pero, desde los años setenta, decayó considerablemente. A partir de entonces, las medallas acuñadas para conmemorar las gestas del rey cada vez más dejaron de inspirarse en las de los emperadores romanos, para dar paso a una nueva retórica en forma de estadística (baste un ejemplo: «80 ciudades capturadas», 1675).

Ediciones Universidad de Salamanca / అ@@ Stud. his., H. ${ }^{a}$ mod., 43, n. 2 (2021), pp. 339-368 
fallecimiento de su antecesor, no alcanzaba la plenitud de su poder hasta la finalización del funeral del rey saliente, que no contaba con la participación del nuevo príncipe. Al violar esta última regla, concluye Chartier (2003: 141-142), al presenciar el entierro de Enrique IV, Luis XIII arruina definitivamente un ceremonial (que no se volverá a repetir) que revela el misterio de la monarquía, pues hace visible lo que siempre permanece oculto, la efigie, la inmortalidad de la Corona, mientras el cuerpo natural del rey, perecedero, ya no puede ser contemplado, cubierto por el ataúd (véase también Kantorowicz, 1957).

La indiferencia con la que el pueblo acogió la enfermedad y la muerte de Luis XV llevaba tiempo gestándose. El propio monarca además fue testigo del creciente deterioro de su imagen durante la segunda parte de un mandato que concluía, como recuerda Hardy, con numerosas intervenciones policiales, destinadas a atajar el creciente desprecio de la población hacia el soberano:

A diario [anota el librero en su Journal el siete de mayo de 1774, tres días antes de la muerte de Luis XV] se detiene a muchas personas por conversar con demasiada libertad sobre la enfermedad del rey, sin lugar a dudas para dar una lección de circunspección, tanto más cuanto que el número de descontentos aumenta. Se dice que en la calle St. Honoré un hombre había confesado a uno de sus amigos: «¿A mí qué me puede importar esto? No podríamos estar peor» (Hardy citado por Farge, 1994: 191).

Atrás quedaron los tiempos en los que la salud del príncipe desasosegaba a los súbditos:

Se veía la indiferencia en las personas de todos los grupos del Estado [leemos en el Journal el cinco de mayo], tan opuesta a las demostraciones de cariño dadas en 1744 durante el viaje a Nancy, cuando Luis XV se puso gravemente enfermo y que aún no se olvidaban (Hardy citado por Farge, 1994: 191).

Tanto se ha descompuesto la figura del rey, que mientras en 1757, tras el atentado de Damiens, se oficiaron seiscientas misas en París, en 1774 tan solo se celebraron tres. Acaso la trayectoria de Luis XV (Gaxotte, 2013; Petitfils, 2015) difícilmente podía terminar de otro modo: antes de la oleada de malos discursos que sucedieron al frustrado regicidio, antes de la disputa de los billetes de confesión, el monarca, que nunca consiguió hacer olvidar a sus predecesores, vio cómo, en 1739, su confesor le prohibía tocar las escrófulas por hallarse en concubinato con Mme de Mailly. Louis le Bien Aimé dejaba así de cumplir con aquel gesto inmortalizado por Jouvenet en su retrato de Luis XIV, un gesto que repetían los monarcas franceses desde la Edad Media, signo de sus valiosos poderes taumatúrgicos (Bloch, 1924) [ilustración 2].

Ediciones Universidad de Salamanca / @®@@ Stud. his., H. ${ }^{a}$ mod., 43, n. 2 (2021), pp. 339-368 
ILUSTRACIÓn 2: Jean Jouvenet, Louis XIV guérit les scrofuleux, 1690 (Église-Abbaye de Saint-Riquier).

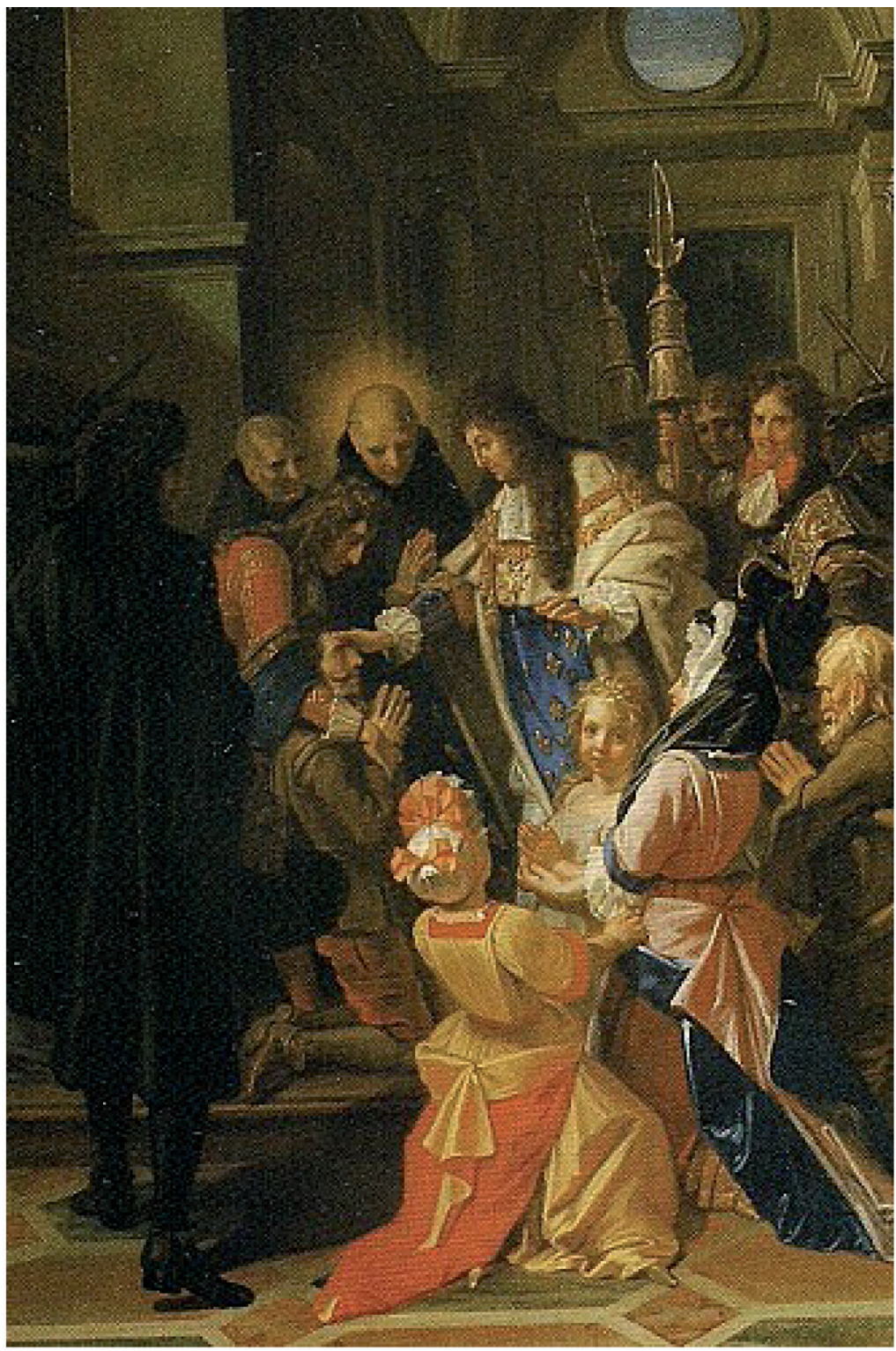

Fuente: Wikimedia Commons (dominio público).

Ediciones Universidad de Salamanca / అ@@ Stud. his., H. ${ }^{a}$ mod., 43, n. 2 (2021), pp. 339-368 


\section{5. «UN DESGRACIADO DE LA HEZ DEL PUEBLO». CONCLUSIÓN}

Para cerrar este artículo, me gustaría regresar a Damiens, visto ahora a través de los ojos del gran gurú de los philosophes. Tras el atentado contra Luis XV, Voltaire, que como comprobamos quedó horrorizado cuando supo de la carta escrita por el reo a Su Majestad, alertaba a d'Alembert ante la temible coyuntura a la que se enfrentaban:

¿Por qué es preciso que los fanáticos se respalden entre ellos y que los philosophes estén desunidos y dispersos? Reúna al rebaño. Coraje. Mucho me temo que Pierre Damiens puede hacerle bastante daño a la filosofía (Voltaire, 1978-1992: vol. IV, p. 924$)^{41}$.

Enviada por el patriarca de Ferney el dieciséis de enero, la misiva llamaba la atención acerca de los peligrosos efectos que el navajazo propinado al monarca podía surtir sobre unos philosophes que disgregados se mostraban muy vulnerables, pero no podía comprender hasta qué punto el escandaloso suceso del cinco de enero era solo el comienzo del «año calamitoso» - como lo denomina Élisabeth Badinter (1999: 265-305) - que apenas había echado a andar. El año en que estalla el caso Damiens será testigo de la acusación de plagio que desacredita a Diderot (cuya primera obra de teatro, Le Fils naturel, es a juicio de Fréron una mala copia de la pieza de Goldoni $\mathrm{Il}$ Vero $\mathrm{Amico}^{42}$, el enfrentamiento entre Rousseau y Diderot y la dimisión de d'Alembert de la dirección de la Encyclopédie, a lo que habría que sumar las crecientes parodias del disperso «rebaño» de Voltaire, como las Petites lettres sur de grands philosophes de Palissot (1757) ${ }^{43}$

41. «Pourquoi faut-il que les fanatiques s'épaulent tous les uns les autres et que les philosophes soient désunis et dispersés? Réunissez le petit troupeau. Courage. J'ai bien peur que Pierre Damiens ne nuise beaucoup à la philosophie» (lettre 4665 [D 7122]: carta de Voltaire a d'Alembert, 16 de enero [de 1757]). Aunque aquí el nombre de pila de Damiens sea Pierre y no Robert-François, no cabe ninguna duda de que Voltaire se refiere al individuo que apuñaló a Luis XV, a quien cita junto a François Ravaillac para afirmar a continuación que ni uno ni otro ni los regicidas que los precedieron pueden ser tachados de deístas, de philosophes.

42. La denuncia vio la luz en el Année littéraire el doce de julio de 1757 (L'Année littéraire..., 1757: vol. IV, pp. 289-300).

43. Tres años más tarde, en concreto el viernes dos de mayo de 1760, se estrenaba en la Comédie Française la pieza titulada Les Philosophes, donde Palissot intentaba retratar los ruines intereses de los enciclopedistas, quienes el diez de marzo del mismo año habían sido criticados con dureza en el discurso de recepción en la Académie Française de Jean-Jacques Le Franc de Pompignan - elegido para ocupar la plaza vacante tras el fallecimiento de Maupertuis -, que desató una intensa guerra de panfletos (Palissot, 1760; Le Franc de Pompignan et Dupré de Saint-Maur, 1760).

Ediciones Universidad de Salamanca / అ@@ Stud. his., H. ${ }^{a}$ mod., 43, n. 2 (2021), pp. 339-368 
y las memorias sobre los caconacs de Joseph Giry de Saint-Cyr (1993) y JacobNicolas Moreau $(1757)^{44}$.

Doce años más tarde, Voltaire volvía a arremeter contra Damiens en su Histoire du Parlement de Paris (Voltaire, 1997b: 210), donde afirmaba que el frustrado regicida era «un malheureux de la lie du peuple» («un desgraciado de la hez del pueblo») ${ }^{45}$.

Las palabras de Voltaire pueden dar lugar a distintas interpretaciones, al menos dos: el sustantivo «lie» («hez») puede referirse exclusivamente a Damiens o ser extensible asimismo -o quizá fundamentalmente - al pueblo. La segunda lectura no debe resultar extraña cuando la sentencia es proferida por uno de los philosophes que más celosamente protegía su elevado estatus, que lo situaba muy por encima del populacho más vil al que pertenecen Damiens o los convulsionarios de SaintMédard ${ }^{46} \mathrm{y}$ también de los «pobres diablos» - como reza el título del famoso poema (Voltaire, 1877) - que intentan en vano acceder a las academias y los salones. Justo en el momento en el que se aprecia una cierta tendencia hacia la autonomización del campo literario (fruto del incremento exponencial de autores, lectores, bibliotecas, colecciones y publicaciones, como también del aumento de los permisos tácitos ${ }^{47} \mathrm{y}$ de los nuevos contratos editoriales, que estipulan para los escritores retribuciones económicas cada vez más sustanciosas), el autor de El siglo de Luis XIV cierra filas en torno a una concepción profundamente elitista de la cultura y aborrece a quienes malviven de su pluma en las buhardillas parisinas, que deberían, según su parecer, abandonar definitivamente esta suerte y aprender un oficio útil:

Cien autores compilan para ganarse el pan [leemos en la voz «Autores» del Diccionario filosófico] y veinte gacetilleros hacen el extracto, la crítica, la apología, la sátira de esas compilaciones con vistas a ganarse también ellos el pan, porque no tienen una profesión [...] Los verdaderos autores son los que han triunfado en un arte verdadero, ya sea en la epopeya, en la tragedia, en la comedia, en la historia o

44. Más tarde Giry de Saint-Cyr publicará un nuevo título en la línea de los dos ya citados, aunque en este caso se trata de una sucesión de fragmentos extraídos de diversas obras firmadas por los philosophes ([Giry de Saint-Cyr], 1758).

45. Según el philosophe, también forman parte de la «lie du peuple» François Ravaillac - el asesino de Enrique IV - y los convulsionnaires de Saint Médard (Voltaire, 1997b: 40, 194).

46. «Hay siempre en la nación gentes que no tienen ningún trato con las personas honradas, que no son del siglo, inaccesibles a los progresos de la nación, y sobre las cuales la atrocidad del fanatismo conserva su imperio, como ciertas enfermedades que sólo atacan a la plebe más baja» (Voltaire, 1996: 439). El citado fragmento pertenece al capítulo que El siglo de Luis XIV dedica al jansenismo, donde Voltaire denigra la milagrosa curación de Mme Lafosse (1725), a la que el autor había apoyado en su momento, testificando a su favor y ofreciéndole una suma de dinero que ella rechazó.

47. A diferencia de los permisos «públicos», los permisos «tácitos» no requerían la aprobación del canciller. Se usaban para autorizar la impresión de títulos que no podían ser avalados oficialmente, pero que no eran tan peligrosos como para ser censurados.

Ediciones Universidad de Salamanca / అ@@ Stud. his., H. ${ }^{a}$ mod., 43, n. 2 (2021), pp. 339-368 
en la filosofía; quienes han enseñado o encantado a los hombres. Los otros de los que hemos hablado son entre las gentes de letras lo que son los zánganos entre los pájaros (Voltaire, 1878: 499-500) ${ }^{48}$.

Damiens no solo está loco — según la versión oficial y el propio Voltaire ${ }^{49}$-, sino que además su humilde condición lo inhabilita de antemano, lo reduce de una vez por todas al silencio, el mismo que según el patriarca de Ferney deberían respetar escrupulosamente los representantes de la baja literatura. Más aún que los habitantes de Grub Street ${ }^{50}$, los hombres y mujeres del pueblo son excluidos, denigrados, ninguneados no solo por Voltaire, sino por la práctica totalidad de los hombres de letras. Quienes se consideran a sí mismos los verdaderos portavoces de la multitud iletrada apuestan por una clara distinción entre la emergente opinión pública y la más que sospechosa opinión popular: según d'Alembert (1779: IX), el historiador «suele distinguir al público verdaderamente ilustrado, que debe guiar su pluma, de esa multitud ciega y ruidosa» ${ }^{51}$. Condorcet (1993: 140) es aún más claro:

48. «Cent auteurs compilent pour avoir du pain, et vingt folliculaires font l'extrait, la critique, l'apologie, la satire de ces compilations, dans l'idée d'avoir aussi du pain, parce qu'ils n'ont point de métier [...] Les auteurs véritables sont ceux qui ont réussi dans un art véritable, soit dans l'épopée, soit dans la tragédie, soit dans la comédie, soit dans l'histoire, ou dans la philosophie; qui ont enseigné ou enchanté les hommes. Les autres dont nous avons parlé sont parmi les gens de lettres ce que les frelons sont parmi les oiseaux». El Dictionnaire philosophique, al que pertenece la citada entrada «Auteurs», apareció por vez primera en 1764, pero la obra fue creciendo en las sucesivas ediciones que fueron publicadas mientras vivía Voltaire - en 1765, 1767, 1769 (titulada La Raison par alphabet), 1770, 1773, 1775, 1776 y 1777-. Además, de 1770 a 1772 vieron la luz los nueve volúmenes de las Questions sur l'Encyclopédie, que contienen aportaciones interesantes a algunas de las voces del Dictionnaire philosophique.

49. En el capítulo 37 del Précis du siècle de Louis XV, dedicado al atentado de 1757, Voltaire dice de Damiens que «era un hombre cuyo humor sombrío y ardiente siempre se había inclinado a la demencia» ["c'était un homme dont l'humeur sombre et ardente avait toujours ressemblé à la démence»] (Voltaire, 1997a: 216). «Este desgraciado - concluye Voltaire (1997a: 224) - no era más que un insensato fanático, menos abominable en realidad que Ravaillac y Jean Châtel, pero más loco, y no tenía más cómplices que estos dos energúmenos. Por lo general, los únicos cómplices de esos monstruos son fanáticos cuyos sesos enardecidos encienden, sin saberlo, un fuego que va a abrazar a espíritus débiles, insensatos y atroces» [«ce malheureux n'était donc qu'un insensé fanatique, moins abominable à la vérité que Ravaillac et Jean Châtel, mais plus fou, et n'ayant pas plus de complices que ces deux énergumènes. Les seuls complices, pour l'ordinaire, de ces monstres sont des fanatiques dont les cervelles échauffées allument, sans le savoir, un feu qui va embraser des esprits faibles, insensés, et atroces»].

50. Grub Street es una calle londinense que alojaba a menudo a escritorzuelos, a los buscavidas del mundillo literario. Uso, por tanto, la expresión como una metáfora, como una denominación que engloba a los gacetilleros, libelistas y autores de obras clandestinas estudiados por Robert Darnton (2003a).

51. «A souvent tendance à distinguer le public vraiment éclairé, qui doit guider sa plume d'avec cette multitude aveugle et bruyante».

Ediciones Universidad de Salamanca / @®@@ Stud. his., H. ${ }^{a}$ mod., 43, n. 2 (2021), pp. 339-368 
Cuando se habla de opinión, hay que distinguir tres especies: la opinión de las personas ilustradas, que precede a la opinión pública y acaba dictándole la ley; la opinión cuya autoridad genera la opinión del pueblo; la opinión popular en fin, que es la de la parte del pueblo más estúpida y miserable ${ }^{52}$.

De un solo golpe estas dos citas ponen patas arriba las visiones excesivamente consoladoras (o hagiográficas) del movimiento ilustrado, que, como afirma Robert Darnton, si bien se diseminó a través de muchos lugares (Londres, Ámsterdam, Milán...), se definió como una causa en el París de Voltaire y la Encyclopédie, como una campaña orquestada por una elite que inventó para sí una nueva denominación, que se ajustó a un nuevo tipo ideal, el philosophe, «en parte hombre de letras, en parte hombre de mundo metido de cabeza en el uso de las letras para liberar al mundo de la superstición» (Darnton, 2003b: 292) (33 $^{\text {. }}$

El objetivo último de este movimiento no consistía en la creación de un corpus doctrinario capaz de mostrar a los lectores cada vez más numerosos las bondades del ejercicio racional. Antes bien, tenía que ver con la instauración de una nueva elite intelectual que supo beneficiarse del debilitamiento de las viejas estructuras que sostenían el edificio del Antiguo Régimen, que pudo aprovecharse ante todo de la crisis de legitimidad sufrida por una monarquía agujereada por los innumerables malos discursos que, como los registrados a propósito del caso Damiens, lanzaban sus invectivas contra el símbolo por excelencia de la nación, el soberano cuya buena fortuna tras el fallido atentado era lamentada por no pocos hombres y mujeres del pueblo.

\section{BIBLIOGRAFÍA}

\subsection{Fuentes primarias}

- Archivos:

Archives Nationales, série X (Parlement de Paris): X ${ }^{1 A}$ 8497-8498 (Parlement civil, Conseil secret, affaire Damiens).

- Prensa:

Amsterdam. Avec privilège de Nos Seigneurs les États de Hollande et de West-Frise [Gazette d'Amsterdam] [1663-1795]. Bibliothèque nationale de France: G-4292-4398.

52. «Quand on parle d'opinion, il faut en distinguer trois espèces: l'opinion des gens éclairés, qui précède l'opinion publique et finit par lui faire la loi; l'opinion dont l'autorité entraîne l'opinion du peuple; l'opinion populaire en fin, qui reste celle de la partie du peuple la plus stupide et la plus misérable».

53. El historiador norteamericano aboga por una «deflación» de la Ilustración: no podemos aplicar esta etiqueta a la práctica totalidad del pensamiento occidental en el siglo XVIII, sino que hemos de reconocer bajo este nombre un movimiento concreto que tomó cuerpo, ante todo, en la capital francesa hacia 1750.

Ediciones Universidad de Salamanca / 요 Stud. his., H. ${ }^{a}$ mod., 43, n. 2 (2021), pp. 339-368 
VÍCTOR CASES MARTÍNEZ

EL CASO DAMIENS Y LA DESACRALIZACIÓN DE LA MONARQUÍA FRANCESA

Gazette [de France] [1631-1792]. Bibliothèque nationale de France: MICROFILM M-197.

L'Année littéraire, ou Suite des Lettres sur quelques écrits de ce temps [1754-1791]. Bibliothèque nationale de France: MICROFILM M-26.

Le Courrier [d'Avignon] [1733-1768]. Bibliothèque nationale de France: MFILM 4-LC2-65.

- Resto de fuentes primarias:

Alembert, d' (1779). Éloges lus dans les séances publiques de l'Académie française. Paris: Panckoucke/Moutard, Préface [lue à la séance publique du 25 août 1772], V-XXXIV.

Arrêt de la cour de Parlement contre la famille de Robert-François Damiens (1757). Paris: P.-G. Simon.

Arrêt de la Cour de Parlement contre Robert-François Damiens, par lequel il est déclaré dument atteint et convaincu de crime de parricide (1757). Lyon: P. Valfray.

Barbier, E.-J.-F. (1857-1866). Chronique de la Régence et du règne de Louis XV (17181763) ou Journal de Barbier. 1 ère édition complète conforme au manuscrit autographe de l'auteur. Paris: Charpentier, 8 vol. https://gallica.bnf.fr/ark:/12148/bpt6k2039424

Collé, Ch. (1868). Journal et mémoires de Charles Collé sur les hommes de lettres, les ouvrages dramatiques et les événements les plus mémorables du règne de Louis $X V:$ 1748-1772. Nouvelle éd. augmenté de fragments inédits recueillis dans le ms. de la Bibliothèque impériale du Louvre, avec une introduction et des notes par $\mathrm{H}$. Bonhomme. Paris: Firmin Didot et frères et fils et Cie, 3 vol. https://catalogue.bnf. fr/ark:/12148/cb339867669

Condorcet, J.-A.-N. de Caritat, marquis de (1993). Réflexions sur le commerce des bleds. Micro Graphix (reproduction de l'éd. de Londres, 1776). https://gallica.bnf.fr/ ark:/12148/bpt6k417150

Croÿ-Solre, E. de (1906-1907). Journal inédit du duc de Crö̈ (1718-1784). Publié, d'après le ms. autographe conservé à la bibliothèque de l'Institut, avec introduction, notes et index par le Vte de Grouchy et P. Cottin. Paris: Flammarion, 4 vol. https://catalogue. bnf.fr/ark:/12148/cb341561883

[Giry de Saint-Cyr, J.] (1758). Catéchisme et décisions de cas de conscience, à l'usage des Cacouacs, avec un discours du patriarche des Cacouacs pour la réception d'un nouveau disciple. Cacopolis. https://gallica.bnf.fr/ark:/12148/bpt6k1085592

[Giry de Saint-Cyr, J.] (1993). Premier mémoire pour servir à l'bistoire de Cacouacs [inséré dans le Mercure de France, premier volume du mois d'octobre 1757, p. 15, sous le titre d'Avis utile]. En J.-L. Vissière (éd.), La Secte des empoisonneurs: polémique autour de l'Encyclopédie de Diderot et d'Alembert. Aix-en-Provence: Publications de l'Université de Provence, 40-42.

Grosley, P.-J. (1757). Les iniquités découvertes. Londres [Paris].

Le Breton, A.-A. (Éd.) (1757). Pièces originales et procédures du procès fait à Robert-François Damiens, tant en la Prévôté de l'Hôtel qu'en la cour de Parlement. Paris: P.-G. Simon.

Le Franc de Pompignan, J.-J. et Dupré de Saint-Maur, N.-F. (1760). Discours prononcés à l'Académie française, le lundi 10 mars 1760, à la réception de M. Lefranc de Pompignan. Paris: chez Brunet.

Mandrin, L. (1976). Testament politique de Louis Mandrin. Paris: Éditions d'Histoire Sociale.

Ediciones Universidad de Salamanca / 요 Stud. his., H. ${ }^{a}$ mod., 43, n. 2 (2021), pp. 339-368 
[Mopinot de la Chapotte, A.-R.] (1905). Sous Louis XV le Bien-Aimé. Correspondance amoureuse et militaire d'un officier pendant la guerre de Sept Ans (1757-1765). Éditée par J. Lemoine. Paris: Calmann-Lévy.

[Moreau, J.-N.] (1757). Nouveau mémoire pour servir à l'histoire de Caconacs. Amsterdam [Paris]. https://gallica.bnf.fr/ark:/12148/bpt6k838027

Palissot de Montenoy, Ch. (1757). Petites lettres sur de grands philosophes. Paris. https:// gallica.bnf.fr/ark:/12148/bpt6k679607

Palissot de Montenoy, Ch. (1760). Les Philosophes, comédie, en trois actes, en vers. Représentée pour la première fois par les Comédiens Français ordinaires du Roi le 2 Mai 1760. Paris: Duchesne. https://gallica.bnf.fr/ark:/12148/bpt6k71017c

Ravaisson-Mollien, F. (Éd.) (1891). Archives de la Bastille: documents inédits. Paris: A. Durand et G. Pedone-Lauriel, vol. XVII. Règne de Louis XV (1757 à 1762). https:// gallica.bnf.fr/ark:/12148/bpt6k83167w

Ravaisson-Mollien, F. et Ravaisson-Mollien, L. (Éds.) (1903). Archives de la Bastille: documents inédits. Paris: A. Durand et G. Pedone-Lauriel, vol. XVIII. Règne de Louis XV (1757 à 1767). https://gallica.bnf.fr/ark:/12148/bpt6k831687

[Voltaire] (1877). Le Pauvre diable, ouvrage en vers aisés de feu de M. Vadé, mis en lumière par Catherine Vadé, sa cuisine, dédié à Maître Abraham**** [Chaumeix]. En CEuvres complètes de Voltaire. Nouvelle édition, avec notices, préfaces, variantes, table analytique, les notes de tous les commentateurs et des notes nouvelles, conforme pour le texte à l'édition de Beuchot, enrichie des découvertes les plus récentes et mise au courant des travaux qui ont paru jusqu'à ce jour. Paris: Garnier frères, vol. X. Contes en vers, satires, épîtres, poésies mêlées, 97-113. https://gallica.bnf.fr/ark:/12148/bpt6k4113266

Voltaire (1878). Auteurs. En Euvres complètes de Voltaire. Nouvelle édition, avec notices, préfaces, variantes, table analytique, les notes de tous les commentateurs et des notes nouvelles, conforme pour le texte à l'édition de Beuchot, enrichie des découvertes les plus récentes et mise au courant des travaux qui ont paru jusqu'à ce jour. Paris: Garnier frères, vol. XVII. Dictionnaire philosophique, tome I, 496-501. https://gallica.bnf.fr/ ark:/12148/bpt6k411333d/f509.image

Voltaire (1978-1992). Correspondance. Éditée par Th. Besterman, notes de Besterman traduites et adaptées par F. Deloffre. [Paris]: Gallimard, 13 vol.

Voltaire (1996). El siglo de Luis XIV. Trad. de N. Orfila Reynal. México: FCE.

Voltaire (1997a). Précis du siècle de Louis XV. Paris: Bibliothèque nationale de France.

Voltaire (1997b). Histoire du Parlement de Paris. Paris: Bibliothèque nationale de France.

\subsection{Fuentes secundarias}

Badinter, É. (1999). Les passions intellectuelles, vol. II. Exigence de dignité (1751-1762). Paris: Fayard (trad. española: Las pasiones intelectuales, vol. II. Exigencia de dignidad (1751-1762). Trad. de A. Falcón. Buenos Aires: FCE, 2009).

Baker, K. M. (1987). Politique et opinion publique sous l'Ancien Régime [trad. de J.-F. Sené]. Annales ESC, 1, 41-71. https://doi.org/10.3406/ahess.1987.283368

Ediciones Universidad de Salamanca / @®@@ Stud. his., H. ${ }^{a}$ mod., 43, n. 2 (2021), pp. 339-368 
Bloch, M. (1924). Les rois thaumaturges: étude sur le caractère surnaturel attribué à la puissance royale particulièrement en France et en Angleterre. Publications de la Faculté de Lettres de l'Université de Strasbourg (réédition corrigée: Gallimard, 1983; trad. española: Los reyes taumaturgos. Estudio sobre el carácter sobrenatural atribuido al poder real, particularmente en Francia e Inglaterra. Trad. de M. Lara y J. C. Rodríguez Aguilar. México: FCE, 2006).

Blom, Ph. (2007). Encyclopédie. El triunfo de la razón en tiempos irracionales. Trad. de J. Calzada. Barcelona: Anagrama.

Burke, P. (2003). La fabricación de Luis XIV. Trad. de M. Sáenz de Heredia. San Sebastián: Nerea.

Cases, V. (2006). Tecnologías de poder: el caso Damiens. En J. Valdivieso, M. A. Capó, J. L. Llinàs y E. Riera (Eds.), Actas del 43 Congreso de Filósofos Jóvenes. Filosofía y Tecnología(s) [recurso electrónico]. Palma de Mallorca: Universitat de les Illes Balears/ Associació Filosófica de les Illes Balears, 1-13.

Chartier, R. (2003). Espacio público, crítica y desacralización en el siglo XVIII. Los orígenes culturales de la Revolución Francesa. Trad. de B. Lonné. Barcelona: Gedisa.

Darnton, R. (2003a). Edición y subversión. Literatura clandestina en el Antiguo Régimen. Trad. de L. Vidal. Madrid: Turner/FCE.

Darnton, R. (2003b). La dentadura postiza de George Washington [trad. de A. Saborit]. En El coloquio de los lectores. Ensayos sobre autores, manuscritos, editores y lectores. México: FCE, 285-309.

Elias, N. (1982). La sociedad cortesana. Trad. de G. Hirata. México: FCE.

Farge, A. (1992). Dire et mal dire. L'opinion publique au XVIIIe siècle. Paris: Seuil.

Farge, A. (1994). La vida frágil. Violencia, poderes y solidaridades en el París del siglo XVIII. Trad. de G. Montes de Oca y M. Jiménez Mier y Terán. México: Instituto Mora.

Foucault, M. (2000). Vigilar y castigar. Nacimiento de la prisión. Trad. de A. Garzón del Camino. Madrid: FCE.

Gaxotte, P. (2013). Le siècle de Louis XV. Paris: Tallandier.

Giesey, R. E. (1987). The King Imagined. En K. M. Baker (Ed.), The French Revolution and the Creation of Modern Political Culture, vol. I. The Political Culture of the Old Regime. Oxford: Pergamon Press, 41-59.

Kantorowicz, E. H. (1957). The King's Two Bodies: a Study in Medieval Political Theology. Princeton: Princeton University Press (trad. española: Los dos cuerpos del rey. Trad. de S. Aikin Araluce y R. Blázquez Godoy. Madrid: Alianza, 1985).

Koselleck, R. (1965). Crítica y crisis del mundo burgués. Trad. de R. de la Vega. Madrid: Rialp. Merrick, J. W. (1990). The Desacralization of the French Monarchy in the Eighteenth Century, Baton Rouge/London: Louisiana State University Press.

Petitfils, J.-C. (2015). Louis XV. Paris: Éditions France loisirs.

Popkin, J. D. (1987). The Prerevolutionary Origins of the Political Journalism. En K. M. Baker (Ed.), The French Revolution and the Creation of Modern Political Culture, vol. I. The Political Culture of the Old Regime. Oxford: Pergamon Press, 203-224.

Ediciones Universidad de Salamanca / 
Rétat, P. (Dir.) (1979). L'attentat de Damiens. Discours sur l'événement au XVIIIe siècle. Paris/Lyon: CNRS/Presses Universitaires de Lyon. https://doi.org/10.4000/books. pul.551

Rétat, P. (Dir.) (2001). La Gazette d'Amsterdam, miroir de l'Europe au XVIIIe siècle. Oxford: Voltaire Foundation.

Romon, C. (1983). L'affaire des «enlèvements d'enfants» dans les archives du Châtelet (1749-1750). Revue historique, 270(547), 55-85.

Thelliez, B. (2002). L'homme qui poignarda Louis XV. Robert-François Damien. Paris: Tallandier.

Van Kley, D. K. (1984). The Damiens Affair and the Unraveling of the Ancien Régime, 17501770. Princeton: Princeton University Press. https://doi.org/10.1515/9781400857289

Van Kley, D. K. (2002). Los orígenes religiosos de la Revolución Francesa. De Calvino a la Constitución civil (1560-1791). Trad. de C. González del Yerro Valdés. Madrid: Encuentro.

Zysberg, A. (2002). La monarchie des Lumières, 1715-1786. Paris: Seuil.

Ediciones Universidad de Salamanca / @®@ Stud. his., H. ${ }^{a}$ mod., 43, n. 2 (2021), pp. 339-368 